\title{
Verby die geweld van die metafisika: \\ Die Christelike erfenis en sekularisasie
}

\author{
Marinus Schoeman \\ Departement Filosofie \\ Universiteit van Pretoria
}

\begin{abstract}
Beyond the violence of metaphysics: The Christian tradition and secularisation

This essay reinterprets Christian faith in terms of the contemporary philosophical discourse on nihilism and the "end" of metaphysics, especially Heidegger's ontology of "decline." If Christianity is to regain its relevance in the contemporary world, it should purge itself from remnants of the natural religions as well as metaphysical beliefs, because they are instrumental in concealing (and thereby perpetuating) the arbitrary violence on which communities and their moral systems are founded. Christianity can play a meaningful role in unmasking these beliefs, thus paving the way for a "healthy" secularism and an ethics of love and non-violence.
\end{abstract}

\section{DIE "EINDE" VAN DIE MODERNITEIT}

Dat die moderniteit tot 'n "einde" gekom het, of minstens voor 'n krisis te staan gekom het, het al 'n gemeenplaas geword in die eietydse filosofiese diskoers. Ons tyd staan in die teken van die verval en ontbinding van die vernaamste teorieë van die moderne: die positivistiese sciëntisme, en die Hegeliaans-Marxistiese historisme. Albei hierdie meta-narratiewe of meesterverhale (Lyotard) van die moderne het hulle wortels in die ateïstiese rasio-

* Voordrag gelewer op 20 Augustus 1999 tydens die simposium van die Komitee vir Kultuurkritiek van die Raad vir Apostolaat (Nederduitsch Hervormde Kerk van Afrika), gehou op die kampus van die Universiteit van Pretoria. 
nalisme: By die sciëntisme neem dit die vorm aan van 'n geloof in die eksklusiewe waarheid van die eksperimentele wetenskap, en by die historisme kom dit neer op die vertroue dat die geskiedenis ' $n$ inherente dinamika het wat noodwendig afstuur op mense se totale emansipasie van enige mag of gesag buite hulleself en hulle rasionele vernuf. In geen van beide hierdie perspektiewe was daar vir die godsdiens enige plek nie. Godsdiens was hoogstens 'n tydelike verskynsel; 'n vergissing wat mettertyd deur die wetenskaplike rasionaliteit ontkrag sou word, of 'n moment wat oorwin sou word deur die ontwikkeling van die rede na voller en meer "outentieke" vorme van selfbewussyn. Maar vandag skyn sowel die geloof in die "objektiewe" waarheid van die eksperimentele wetenskappe, as die vertroue in die vooruitgang van die rede tot die volle verligting daarvan, juis agterhaalde opvattings te wees. Die onttowering (Max Weber) van die wêreld het ook 'n radikale onttowering van die idee van die onttowering self teweeggebring. Anders gestel: ontmitologisering het uiteindelik teen sigself gekeer deur die ideaal van die afskaffing van die mite sélf as 'n mite te herken. Hierdie insig open nuwe moontlikhede vir nadenke en gesprek oor die plek van die religie in ons leefwêreld. My eie nadenke in dié verband is geïnspireer deur bepaalde opvattings van Nietzsche en Heidegger, waarby ek vervolgens kortliks wil stilstaan.

\section{DIE EINDE VAN DIE METAFISIKA EN DIE NIHILISME: NIETZSCHE EN HEIDEGGER}

Dit is bekend dat Nietzsche en Heidegger die nihilisme beskou as eindpunt van die moderniteit. Daarby dui die nihilisme vir beide hierdie denkers op die einde van die metafisika. Volgens Nietzsche beteken die nihilisme die definitiewe verval van die geloof in die syn as die sogenaamde "ware" (lees: "objektiewe") werklikheid, waarvan die denke min of meer adekwate voorstellings sou kon maak. Hierdie vervalsgeskiedenis beskryf Nietzsche onder meer in 'n beroemde passasie (in sy Götzen-Dämmerung) getitel "Hoe die ware wêreld uiteindelik tot ' $n$ fabel geword het." Die ganse geskiedenis van die (Westerse) metafisika - vanaf Plato tot en met die moderne sciëntisme - word ontmasker as die geskiedenis van 'n toenemende subjektivering van die syn en die waarheid. Subjektivering beteken hier die uitholling, vervlugtiging en uiteindelike nihilisering van die syn en die 
waarheid deur dit te herlei tot dit wat deur die mens, dit wil sê die "wil tot mag," voorgestel word.

Heidegger neem in wese hierdie Nietzscheaanse rekonstruksie van die geskiedenis van die Westerse metafisika oor. Vir hom beteken dit egter, meer eksplisiet as by Nietzsche, dat met die nihilisme (die uitdruklike vasstelling dat die syn en die waarheid blote konstruksies is, produkte van die subjek) die metafisika tot 'n einde gekom het. Hierdie einde moet as einde bedink word ter voorbereiding van 'n "nuwe" soort denke "anderkant" of "verby" die metafisika. Vir Heidegger beteken dit 'n denke verby die greep van die identiteitslogika wat daarop uit is om 'n identiteit te stig tussen die denke enersyds, en die sogenaamde objektiewe werklikheid andersyds. Die afwysing oftewel "Überwindung" van die metafisika beteken egter geensins dat die identiteitslogika van die metafisika as 'n dwaling ontmasker word, wat dan vervang moet word deur 'n meer "ware" of "objektiewe" begrip van die syn nie. Op hierdie wyse sou ons nog steeds vasgevang bly binne die metafisika van die objektiwiteit. Heidegger se kritiek op die metafisika het na alles nie soseer 'n teoretiese nie, maar veral 'n eties-politieke grondslag. Die metafisika van die objektiwiteit resulteer naamlik in 'n denkhouding wat die waarheid van die syn vereenselwig met die berekenbaarheid, meetbaarheid en uiteindelike manipuleerbaarheid van die werklikheid as tegnies-wetenskaplike objek. Hierdeur word die voorwaardes geskep vir wat Adorno die wêreld van die "totale organisasie" sal noem. In so 'n wêreld dreig ook die menslike subjek om, op 'n noodlottige wyse, 'n onderdeel te word van die algemene meganisme van produksie en verbruik. Juis mense se poging om vry en outonoom te word het hulle, ironies genoeg, uitgelewer aan nuwe vorme van knegskap en heteronomie.

Die enigste "uitweg" uit die impasse van ons huidige situasie is dus om die syn te bedink in nie-metafisiese terme. Dit beteken vir Heidegger - en hierin lê sy radikaliteit dat ons die geskiedenis van die metafisika moet verstaan as die geskiedenis van die syn self, en nie slegs as die geskiedenis van menslike dwalinge nie. Dit beteken verder dat die syn self ' $n$ nihilistiese bestemming het, dat dit sigself terugtrek, onttrek, verberg, verswak. Paradoksaal genoeg word die syn geopenbaar juis op die moment waarin dit sigself onttrek. In en deur die eie verswakking word die syn juis geopenbaar, en dit word op 'n epogale manier duidelik gemanifesteer in die einde van die metafisika - in die problematies-word van iedere vorm van objektivisme - wat so kenmerkend van ons eie tyd is. 


\section{HEIDEGGER SE ONTOLOGIE VAN DIE VERSWAKKING EN DIE CHRISTELIKE ERFENIS}

Uit die voorafgaande het dit hopelik duidelik geword waarom Heidegger se filosofie as 'n "swak ontologie" of ontologie van die verswakking (Vattimo) gedui kan word. Dit is presies hier waar daar myns insiens 'n vrugbare aanknopingspunt gevind kan word tussen Heidegger en die Christelike tradisie. Veral my kennismaking met die werk van René Girard het my vermoede versterk dat daar 'n wesenlike affiniteit bestaan tussen Heidegger se ontologie en die Christelike geloof, met name die leer oor die menswording van die Seun van God.

Girard ontwikkel in onder meer La violence et le sacré 'n interessante teorie oor die oorsprong en ontwikkeling van die menslike beskawing. Dit berus op die tese dat wat vanuit 'n suiwer natuurlike, menslike gesigspunt heilig genoem word, ten diepste verwant is aan geweld. Die menslike samelewings, so lui Girard se argument ongeveer, word byeengehou deur ' $n$ magtige impuls: die mimetiese begeerte (begeerte om na te boots). Hierdie impuls lê egter gelyktydig ook aan die wortel van die krisisse wat dreig om 'n samelewing te laat ontbind. Die mimetiese begeerte vind naamlik uiting in die drang om die goedere wat aan 'n ander behoort vir jouself toe te eien, en dit lei tot 'n oorlog van almal teen almal. As sake eers so 'n loop geneem het, is daar maar een manier om die eendrag weer te herstel, en dit is om 'n sondebok te vind op wie die geweld geprojekteer kan word - ongeveer soos in 'n voetbalstadion waar die toeskouers eenparig probeer om hulle woede op die skeidsregter te ontlaai. Aangesien die sondebok, deurdat dit die einde van die oorlog bewerkstellig en die basis van die samelewing herstel, 'n onmisbare funksie vervul, word dit met heilige attribute beklee en word dit die objek van verering, al bly dit ook in wese 'n slagoffer.

Die "natuurlike" kenmerke van die heilige vind mens ook in die Bybel terug. Die Christelike teologie verewig die slagoffermeganisme deur Jesus Christus as die "volmaakte slagoffer" te beskou. Deur sy oneindig waardevolle offer - die menslik-goddelike persoon van Jesus is immers oneindig - voorsien Hy in die behoefte van God om die sonde van Adam te bestraf. Girard beweer, volgens my heeltemal tereg, dat die lesing van die Skrifboodskap in terme van slagofferskap nie korrek is nie. Jesus het nie ' $n$ mens geword om vir God 'n geskikte slagoffer vir God se toorn te bied nie, maar Hy kom juis na die 
wêreld om die band tussen die heilige en die geweld aan die lig te bring en daarmee ook tot niet te maak. Hy word doodgemaak omdat so 'n onthulling nie verdra kan word deur 'n mensheid wat gewortel is in die gewelddadige tradisie van die offergodsdienste nie.

Dat die Christelike kerke nog steeds oor Jesus as 'n slagoffer praat, getuig slegs van die kragtige oorblyfsels van die natuurgodsdienste in die hart van die Christendom. Die Bybelse openbaring, die Ou ẹn die Nuwe Testament, kan daarteenoor gesien word as 'n lang leerproses oor die verhouding tussen God en mens, 'n proses waarin steeds duideliker afstand geneem word van die natuurgodsdienste en die offer. Hierdie proses is nog nie voltooi nie, en dit verklaar presies die oorlewing van offerelemente in die Christelike teologie.

\section{MENSWORDING VAN GOD EN SEKULARISASIE}

Van beslissende belang in die werk van Girard is enersyds die eksplisiete erkenning dat die goddelike leerproses oftewel die openbaring nog steeds aan die gang is en dus nie voltooi is nie, en andersyds die idee van die vleeswording as ontbinding van die heilige in soverre dit gewelddadig is. Girard steun hier op die erfenis van talle twintigste-eeuse teoloë wat die verskil tussen Christelike geloof en "godsdiens" benadruk, waarby laasgenoemde vereenselwig word met die natuurlike neiging van mense om hulleself as afhanklik van 'n opperwese te beskou. Maar juis omdat hierdie opperwese aan ons natuurlike neigings beantwoord, word dit uiteindelik niks anders nie as 'n projeksie van menslike verlangens, en staan dit weerloos teen die kritiek van denkers soos Feuerbach, Marx en Freud.

As ons werklik erns wil maak met die nihilisme, en vanuit hierdie konteks hoegenaamd nog iets positief of betekenisvol wil terugvind in die Christelike erfenis, moet ons myns insiens die werk van Girard ter harte neem, maar dit ook nog 'n stap verder voer. Ons moet dan erken dat die natuurlik-heilige nie slegs gewelddadig is omdat die slagoffermeganisme 'n godheid veronderstel wat dors na wraak nie, maar ook vir sover dit aan hierdie godheid alle kenmerke van almag, absoluutheid en "transendensie" (ten opsigte van die mens) toeskryf. Dit is presies dié attribute wat deur die natuurteologieë aan God toegedig word. So beskou, is die gewelddadige God van Girard ook die God van die metafisika, dit wil sê die God wat as ipsum esse subsistens al die deur die metafisika bedagte kenmerke van die objektiewe syn in sigself verenig. Die ontbinding van die metafisika 
beteken dan ook die einde van hierdie beeld van God. Dit is dan ook wat Nietzsche bedoel met sy uitspraak "God is dood."

Die einde van die metafisika beteken dat die syn onthul word as gekenmerk deur 'n innerlike neiging om waarheid deur eie verswakking te bevestig. Dit is, soos reeds gesê, die werklik radikale insig wat Heidegger se ontologie van die verswakking wil tuisbring. 'n Mens mis heeltemal die punt van Heidegger se ontologie van die verswakking as jy dit op 'n simplistiese manier toeëien en dit probeer voorhou as 'n soort negatiewe voorbereiding op die terugkeer van die religie. Dit gebeur veral in die godsdiensfilosofieë met 'n eksistensialistiese agtergrond, en dan nog dikwels met 'n beroep op Heidegger, wie se werk deur ' $n$ antropologiserende, eksistensialistiese bril gelees en sodoende totaal verwring word. Ek kom in die volgende onderafdeling hierop terug. Hier wil ek volstaan met die stelling dat die menswording, oftewel die verlaging van God tot die vlak van die mens, wat die Nuwe Testament die kenosis van God noem (vgl Fil 2:7), geïnterpreteer moet word as teken dat die nie-gewelddadige en nie-absolute God van die post-metafisiese tyd gekenmerk word deur dieselfde neiging tot verswakking as dié waarvan die Heideggeriaansgeïnspireerde filosofie praat. Trouens, die ontologie van die verswakking, soos wat dit onder meer in Heidegger se filosofie na vore tree, vertoon myns insiens 'n wesenlike affiniteit met die Christelike boodskap oor die kenosis van God.

Dat daar op die een of ander manier 'n verband bestaan tussen die geskiedenis van die Christelike openbaring en die nihilisme (die onafwendbare verval van die metafisiese pretensie) is na my mening voor die hand liggend. Die geskiedenis van die Christelike godsdiens maak immers nie slegs deel uit van die Westerse geskiedenis in die algemeen nie, maar dit is in vele opsigte konstitutief daarvoor. En dit geld ook vir die moderne tydvak, en meer spesifiek die proses van sekularisasie wat so kenmerkend is van die moderne Weste. Die sekularisasie moet, soos talle denkers (Weber, Troeltsch, Gogarten, ens) reeds aangevoer het, beskou word as inherent aan die Christendom, en daarby as iets wat positief saamhang met die boodskap van Jesus.

Met die term "sekularisasie" word bedoel die proses van "afdrywing" wat die moderne, sekulêre beskawing losmaak van sy sakrale oorsprong. Maar as die natuurlikheilige die gewelddadige meganisme is wat Jesus kom ontmasker het, dan is dit heel moontlik dat die sekularisasie juis 'n positiewe uitkoms is van die leer van Jesus, en nie 
noodwendig in stryd daarmee nie. Meer nog: die sekularisasie kan beskou word as deel van die voortgaande openbaring van God in die wêreld. Dit beteken dat die ontbinding van die sakrale stukture van die Christelike samelewing, die oorgang na 'n etiek van die menslike outonomie, na 'n sekulêre staat, na 'n minder gestrenge letterlikheid by die interpretasie van dogmas en voorskrifte, nie begryp word as ' $n$ verval of 'n afskeid van die Christendom nie, maar as 'n.steeds voller verwesenliking van die Christelike leer van die kenosis, die verlaging van God, die ontkenning van die "natuurlike" kenmerke van die godheid.

Die "positiewe" betekenis van die sekularisasie, dit wil sê die idee dat die sekulêre moderniteit ook en veral 'n voortsetting en 'n ontheiligende interpretasie is van die Bybelse boodskap, is geen vreemde gedagte nie. Hierbo is reeds na figure soos Weber, Troeltsch en Gogarten verwys. Daar is wye aanvaarding vir die tese dat die rasionalisasie van die moderne samelewing ondenkbaar sou wees sonder die perspektief van die Joods-Christelike monoteïsme. 'n Mens kan in vele ander opsigte - altyd verbonde met die idee van ontheiliging van die gewelddadige, outoritêre, absolute heilige van die natuurgodsdienste praat oor die moderniteit as sekularisasie. So kan byvoorbeeld die oorgangsproses van 'n absolute, op Goddelike reg gebaseerde staatsmag, na 'n konstitusionele monargie, en uiteindelik die huidige verteenwoordigende demokrasieë, gemaklik (weliswaar nie uitsluitlik nie) beskryf word in terme van sekularisasie.

Nog 'n outeur na wie in hierdie verband verwys kan word, is Norbert Elias. Hy toon aan dat die moderne vorme van mag gekenmerk word deur 'n formalisering wat die mag steeds meer ontdoen van sy absolute karakter vir sover dit gebonde was aan die soewereiniteit van 'n "sakrale" persoon. In die proses word onder andere ook die moderne subjektiwiteit gesekulariseer. In die oorgang na 'n nuwe sisteem van maatskaplike verhoudings en mag wat veel ingewikkelder is as die verhouding tot 'n enkele soewereine persoon, vind die moderne subjek sigself verplaas (verstrooi) binne 'n ondeurdringbare netwerk van bemiddelings, wat mede daartoe aanleiding gegee het dat die hele nosie van die subjek en die sentrale piek wat dit binne die moderne filosofie inneem, ernstig bevraagteken en ondermyn word (vgl die tema van die "desentrering van die subjek" as grondliggende leitmotif in die kontemporêre filosofiese diskoers). Verder kan daar ook verwys word na die psigo-analise, wat self 'n magtige faktor is in die sekularisasie vir 
sover dit byvoorbeeld die illusie verbreek dat die bewussyn in laaste instansie iets sakraals, iets onaantasbaars en soewerein sou wees (Freud verwys hiema as die verwonding van die narcisme van die ek).

Die beswaar kan geopper word dat die draagwydte van die begrip sekularisasie hier oorspan word deur dit op sovele uiteenlopende verskynsels van toepassing te maak. Ek gee toe dat dit gevaarlik kan wees, en daarom verkies ek om meer in die algemeen van verswakking te praat, en die sekularisasie as 'n geval by uitstek daarvan te beskou. Maar tog bly sekularisasie vir my 'n sentrale term omdat dit die religieuse betekenis van die hele proses onderstreep. Ek is daarvan oortuig dat byna al die hoofkenmerke van die Westerse beskawing hulle struktuur ontleen aan die grondteks van die Joods-Christelike tradisie. Die feit dat ons ons kultuur vandag nie meer eksplisiet as Christelik verstaan nie - inteendeel as sekulêr, ontkersten, post-Christelik beskou, maar tog in die wortels daarvan ten diepste deur hierdie erfenis gevorm is - is volgens my genoeg rede om oor "positiewe" sekularisasie as kenmerk van die moderniteit te praat.

\section{SEKULARISASIE EN DIE TRAGIESE OPVATTING VAN DIE CHRIS- TENDOM. ENKELE OPMERKINGS OOR DIE DIALEKTIESE TEOLO- GIE}

Die teologiese literatuur van hierdie eeu is ryk aan beskouings oor die suiwerende werking van die sekularisasie vir die Christelike geloof, in soverre die sekularisasie 'n geleidelike ontbinding van die elemente van die "natuurlike" religiositeit ten gunste van 'n meer outentieke insig in die ware essensie van die geloof beteken. Hierdie insig is egter dikwels en met name in die dialektiese teologie - verwar met die bevestiging van die absolute transendensie van God ten opsigte van iedere menslike verwagting - 'n bevestiging wat volgens my nog steeds in die rigting wys van 'n "naturalistiese," absolute, dreigende en grillige beeld van die goddelike.

Nieteenstaande die raakpunte wat daar wel is, staan die betekenis wat ek gee aan die sekularisasie as ' $n$ positiewe ontwikkeling van die Christendom diametraal teenoor dié van dialektiese teoloë soos Barth en Gogarten. Die uitkoms van die sekularisasie is nie dat die transendensie van God steeds duideliker aan die lig gebring word deur die geloof te suiwer van 'n te noue verband met die tyd, van die verwagtings van menslike vervol- 
making en van die illusies oor ' $n$ toenemende verligting van die rede nie. Sekularisasie is daarenteen 'n manier waarop die kenosis, wat begin is met die menswording van Christus (en nog vroeër met die verbond tussen God en God se volk), sigself in steeds duideliker terme verwesenlik, en so God se werk voortsit om die mens te leer om die oorspronklik gewelddadige aard van die heilige, en van die maatskaplike lewe self, te oorwin.

Die dialektiese teologie was 'n poging om die "outentieke" leer van die Christelike geloof te "red" deur die kerk en die kerk se verkondigingstaak los te maak van enige konkrete sosio-historiese konteks, insluitende die konteks van die moderne, sekulêre maatskappy. Hierdie strategie kan gesien word as 'n reaksie teen die neiging van die kerk om sigself te sterk te identifiseer met 'n bepaalde historiese realiteit. Die kerk het, in die manier waarop die kerk bepaalde aspekte van die leer en die geloofspraktyk verdedig het, sigself tot eie skade en verleentheid te veel gekompromitteer tot die kultuur van 'n bepaalde historiese wêreld́, wat ten onregte beskou is as die enigste wat in ooreenstemming is met die leer van die evangelie. Die lotgevalle van die verset van die kerk teen die moderne demokrasie, om nie te praat van kwessies soos die veroordeling van Galileï nie, toon duidelik die steeds terugkerende probleem in die geskiedenis van die kerk: die verabsolutering van bepaalde histories-kontingente kaders, waarvan mense gemeen het dat dit nie te skei is van die waarheid van die openbaring nie.

Die neiging van die kerk om die betekenis van die openbaring "verkeerd te begryp" op grond van die kerk se bande met 'n bepaalde historiese realiteit, het, soos Wilhelm Dilthey aangevoer het, ontstaan as gevolg van die feit dat die vroeë Christendom in die laat-antieke wêreld die val van die Romeinse ryk moes opvang. By gebrek aan burgerlike instellings was die pous en die biskoppe toe die enigste gesagsdraers wat in staat was om die minimum-voorwaardes vir die samelewing te verseker (vgl Dilthey 1988).

Maar, alhoewel ek begrip het vir die dialektiese teoloë se verset teen hierdie neiging, kan ek in terme van my opvatting oor die "positiewe" rol van die sekularisasie nie saamgaan met die idee dat die kerk die kerk se leer moet skei van die verwikkeldheid in die geskiedenis nie. En dít lyk vir my na die weg wat gevolg word deur die dialektiese teologie, en ook in die algemeen deur iedere teologie wat (nog steeds in 'n metafisiese sin) die outentieke religieuse ervaring opvat as ontmoeting met 'n volstrekte transendensie - die sogenaamde "gans Andere." 
As die sekularisasie, soos wat ek meen, essensieel deel is van die voortgaande heilsgeskiedenis (die kenosis), dan moet ons teenoor die onregmatige band van die Christelike leer met dese of gene historiese realiteit juis die volledige bereidheid stel om die "tekens van die tyd" te lees. Kortom: ons moet onsself opnuut identifiseer met die geskiedenis, waarby ons ons eie historisiteit sonder voorbehoud moet erken. Ek herhaal: dit is wat Jesus doen in sy lesing en sy (eweseer historiese) "vervulling" van die profesieë van die Ou Testament.

Daar is ook nog 'n tweede aspek van die dialektiese teologie waarmee ek 'n probleem het. Die dialektiese teologie hang myns insiens saam met 'n apokaliptiese of tragiese siening van die Christendom, wat heeltemal onversoenbaar is met my standpunt oor die "positiewe" relasie tussen Christendom en sekularisasie, en wat ek beskou as die laaste groot metafisiese misverstand van die Christelike denke. Hierdie misverstand berus op die idee van 'n radikale skeiding tussen die heilsgeskiedenis en die sekulêre geskiedenis, wat dan sou beteken dat die openbaring uitsluitlik 'n apokaliptiese betekenis het: die openbaring kom neer op die onthulling van die sinloosheid van die wêreldse geskiedenis, in die lig van 'n volstrek anderse gebeure - 'n alteriteit wat totaal onvoorstelbaar is, en in terme waarvan die sekulêre geskiedenis slegs 'n negatiewe betekenis het as dit wat agtergelaat moet word in die paradoks van die "sprong in die geloof." God verskyn as die "gans Andere" wat sigself in ons ervaring veral manifesteer by "katastrofale" gebeutenisse, dit wil sê gebeurtenisse wat alle sekerhede wat ons deur middel van ons eie menslike vermoëns probeer oprig, in gevaar bring of in duie laat stort. Terwyl denkers soos Thomas van Aquino en René Descartes nog gemeen het om die bestaan van God te kan bewys uit die orde van die wêreld, soek die dialektiese teoloë hulle godsbewyse langs die weg van 'n negatiewe antropologie waarin die kwesbaarheid en tragiek van die menslike kondisie vooropgestel word. Die invloed van veral die eksistensialisme (soos reeds hierbo genoem) is hier onmiskenbaar duidelik, asook dié van verskeie ander filosofiese stromings wat skerp krities staan teenoor die moderne Westerse rasionaliteit. 'n Pessimistiese gees het oral begin posvat, en om begryplike redes. Sowel Auschwitz as die vernietiging van die Eurosentriese kolonialisme het die ideologie van die vooruitgang onhoudbaar gemaak. En vandag wil dit voorkom of die talle ongerymdhede van die tegniese wetenskap - van die ekologiese verwoesting tot en met die jongste probleme van die bio-etiek - iedereen tot die 
erkenning bring dat "alleen 'n God ons nog kan red," soos Heidegger dit gestel het in die beroemde onderhoud wat na sy dood gepubliseer is.

My probleem met die apokaliptiese, tragiese opvatting van die Christendom lê veral in die manier waarop dit die wêreldse geskiedenis radikaal ontwaardig of diskrediteer. Dit lyk vir my na 'n ewe onaanvaarbare omkering van die Christendom wat sigself met behulp van die tradisionele metafisika probeer regverdig het. Hiermee gee ons geen enkele tree vooruit ten opsigte van die metafisiese religiositeit van weleer nie, maar wel 'n paar treë agteruit. Welke God is meer waaragtig "Christelik", dit wil sê watter een staan verder weg van die dreigende en gewelddadige godheid van die natuurgodsdienste: die God as die laaste grond van die werklikheid waaroor die Grieks-Christelike metafisika dit gehad het, of die God as die gans Andere van die tragiese religiositeit, wat gevoed word deur die eksistensialistiese denke? As ons aanvaar, soos ek glo ons op basis van die evangelie moet doen, dat die sin van die skepping en die verlossing geleë is in die kenosis, dan sal ons waarskynlik moet erken dat die kontinuïteit wat die klassieke metafisika tussen God en wêreld vasgestel het, suiwerder "kenoties" is as die transendensie wat aan God toegedig word wanneer mens God die "gans Andere" noem. Die regressiewe inslag van die tragiese Christendom lê daarin dat dit 'n soort Ou Testamentiese geloof verteenwoordig wat neig om die menswording van Christus as van ondergeskikte belang te beskou. Die menswording word veral gesien as voorwaarde vir die dood aan die kruis, wat alleen as bevestiging dien van die paradoksale transendensie en alteriteit van God ten opsigte van iedere wêreldse logika.

Maar is die inhoud van die Christelike geloof nie inderdaad so paradoksaal nie dat diegene miskien gelyk het wat meen dat egte geloof ' $n$ sprong is, die bereidheid om die totale alteriteit te aanvaar - juis soos die tragiese en eksistensialistiese opvattings dit wil hê? Ek dink nie dat om gehoor te gee aan selfs die mees paradoksale woorde van die evangelie, 'n sprong en uiteindlik 'n soort "irrasionele" aanvaarding van outoriteit vereis nie. Ek is wel bewus van hoe belangrik in die geskiedenis van die moderne spiritualiteit Pascal se stelling van die weddenskap was, en dat dit waarskynlik tot nog toe die enigste groot alternatief was vir die preambula fidei van die Thomistiese tradisie. Maar ons moet in gedagte hou dat die sogenaamde Pascalse weddenskap, dit wil sê die idee dat die geloofservaring ' $n$ sprong in die paradoks is, 'n tipies moderne idee is, altans in beginsel 
verbonde met die tydperk van die "seëvierende" rede. Pascal was ook 'n wiskundige en teoretikus van die "esprit de géométrie," en bowenal 'n tydgenoot van Descartes. En die paradoks as kenmerk van die Christelike geloof is ook nie toevallig weer deur Kierkegaard opgeneem nie - 'n tydgenoot van Hegel, op 'n ander hoogtepunt (miskien die laaste) van die filosofiese rasionalisme. Maar waar die Cartesiaanse en ook die Hegeliaanse rede nou aan die einde van die pad gekom het, het dit nie meer soveel sin om die geloof so sterk teen die rede af te grens nie.

\section{DIE PERMANENTE OPENBARING}

Hierbo is meermale geïmpliseer dat die Bybelse openbaring beskou moet word as 'n verhaal wat steeds vervolg word, waarin ons betrokke is en wat hom dus nie leen tot 'n "herontdekking" van 'n doktrinêre kern wat vir eens en altyd gegewe en gelykblywend is nie. Die openbaring onthul geen waarheid as objek nie, dit spreek van 'n redding wat steeds aan die gang is. Dit kan ' $n$ mens reeds sien in die verhouding van Christus tot die profete van die Ou Testament. Hy presenteer homself as die outentieke interpretasie van die profesieë, maar beloof daarby aan sy dissipels dat Hy vir hulle die Gees van waarheid sal stuur wat die leer (en dus by implikasie die heilsgeskiedenis) sal voortsit deur die inhoud van die leer telkens weer opnuut te interpreteer.

Heilsgeskiedenis en geskiedenis van die interpretasie is ten nouste met mekaar verbonde. Dit gaan hier nie slegs om die feit dat dit vir ons heil noodsaaklik is om gehoor te gee aan die evangeliese boodskap, dit te begryp en op die juiste manier uit te leef nie. Die heil voltrek sigself in die geskiedenis ook en veral deur ' $n$ hernieude interpretasie van die Heilige Skrif wat poog om steeds meer "waar" te wees, dit wil sê steeds meer in lyn met wat sig in die verhouding tussen Jesus en die Ou Testament afgespeel het: "Julle het gehoor dat gesê is ... maar ek sê vir julle." En veral: "Ek noem julle nie meer diensknegte nie, maar vriende." Die leidraad in die interpretasie wat Jesus van die Ou Testament gee, is die nuwe en hegtere, op liefde gebaseerde verhouding tussen God en mens en derhalwe ook tussen die mense onderling. Die Bybelse openbaring, met die Bybel se volle lading van mites, is op hierdie lering afgestem. Dit blyk onder meer uit die pragtige begin van die Hebreër-brief: "Nadat God baiekeer en op baie maniere in die ou tyd gespreek het tot die vaders deur die profete, het God in hierdie laaste dae tot ons gespreek deur die Seun ...." 
Samevattend kan gesê word dat die openbaring van die heil saamval met die gebeure van die kenosis, die verlaging van God, wat steeds besig is om sigself in die geskiedenis te verwesenlik, en ons aldus steeds verder wegneem van die geweld van die natuurlik-heilige en van die moraal en die maatskaplike orde wat daarmee saamhang. En vanuit hierdie perspektief is die sekularisasieproses, minstens vir sover dit bydra tot die voortgaande ontbinding van iedere naturalistiese heiligheid, wesenlik deel van die Christendom self.

\section{VERBY DIE GEWELD VAN DIE METAFISIKA: 'N ETIEK VAN GEWELDLOOSHEID}

Heidegger se ontologie van die verswakking het, soos reeds gesê, ontstaan as reaksie op die pretensies van die metafisiese objektiwiteit, en spesifiek ook die eties-politieke implikasies daarvan. Juis om etiese redes moet ons probeer om die syn los van die metafisika van die objektiwiteit te dink. Nou is daar hier, soos dit miskien uit die voorafgaande reeds begin deurskemer het, 'n belangrike raakpunt tussen die ontologie van die verswakking en die Christelike erfenis, veral die Christelike voorskrif van die liefde en die afwysing van geweld.

Dat die geskiedenis van die syn 'n nihilistiese bestemming het, 'n neiging om die waarheid van die syn te bevestig deur die mag van die syndes te venninder (die politieke gesag, die dreigende en grillige God van die natuurgodsdienste, of die moderne subjek as laaste instansie van waarheid en waardebepaling), is 'n gedagte wat gemaklik aansluiting vind by die Christelike tradisie. Die Christendom het ons immers ook geleer om God nie as heer nie maar as vriend te beskou; ook dat die wesenlike dinge nie aan die wyse en vername mense geopenbaar word nie, maar aan die nietiges; en dat wie sy of haar siel nie verloor nie, dit ook nie sal red nie, ensovoort.

In die houding van talle mense teenoor die kerk en die Christendom sien ons vandag 'n merkwaardige beweging tussen soeke en ontgogeling. By baie is daar 'n opregte belangstelling in die Christelike leer, maar hulle distansieer hulle gou weer daarvan, omdat die leer geen "woorde van ewige lewe" spreek nie. Die kerk meen dat die kerk se taak vervul kan word deur opnuut 'n starre, teoreties onhoudbare opvatting oor die aard van die mens en die daarop gebaseerde moraal te verkondig. Hierteenoor sou ek, vanuit my 
ervarings met die filosofie, wil beweer dat die ruimte vir 'n terugvinding van die Christendom juis moontlik gemaak word deur die ontbinding van die metafisika, dit wil sê deur die einde van die objektivistiese, dogmatiese filosofieë en van die pretensies van 'n bepaalde kultuur (die Europese) as sou dit die "ware" aard van die mens ontdek en verwesenlik het. En dit is die ervaring nie slegs van filosowe nie, maar van iedereen wat in die pluralistiese realiteit van die laat-moderne samelewing leef. By diegene wat vanuit hierdie ervaring met nuwe belangstelling kyk na die Christendom, kan jy nie aankom met 'n metafisies verpakte dogma wat alleen maar kan beantwoord (en teen wat 'n prys) aan die reaksionêre, regressiewe impulse wat aan die basis lê van sovele fundamentalismes om ons heen nie.

Die Christendom se moontlike relevansie vir ons tyd lê in die leer van die verlaging (kenosis) van God en in die "positiewe" bydrae wat dit lewer tot die voortgaande ontheiliging, oftewel sekularisasie van ons leefwêreld. Dit lê met ander woorde nie in vir ewig vasgelegde leerstukke waartoe ons ons kan wend om uiteindelik in die see van onsekerheid en die Babelse verwarring van die post-metafisiese wêreld vaste grond onder ons voet te kry nie. En tog bied dit 'n bepaalde boodskap - 'n kritiese prinsipe - wat duidelik genoeg is om as oriëntasiepunt te dien ten aansien van hierdie wêreld, en spesifiek ook ten aansien van die sekularisasieproses self. Hierdie boodskap is die boodskap van God se liefde, waarin die kenosis se ware betekenis blyk.

As die kenosis van God en die beginsel van die liefde sentraal gestel word in die verkondiging, dan kan die Christendom 'n betekenisvolle "grondteks," 'n inspirasiebron wees in ons kultuur. Die ontologie van die verswakking het ons leer insien dat die nihilisme nie 'n objektiewe gegewe of 'n "toestand" is nie. Die nihilisme is 'n geskiedenis, 'n nimmereindigende gebeure, 'n lotsbestemming. (Ook as Nietzsche oor die voltooide nihilisme praat, bedoel hy daarmee slegs die nihilisme wat nie meer op reaksionêre wyse as verlies en rou oor die einde van die metafisika beleef word nie, maar as geleentheid tot 'n nuwe posisie van die mens ten opsigte van die syn.) Net so is dit ook gestel met die Christelike gebod van die liefde. Enersyds geld dit onbetwyfelbaar as die hoogste gebod. Die hele Nuwe Testament rig ons op die erkenning daarvan as die hoogste gebod. Die interpretasie wat Jesus van die profesieë in die Ou Testament gee, of beter gestel: die interpretasie van hierdie profesieë wat Hyself is, onthul die ware betekenis daarvan, wat uiteindelik maar op één ding neerkom, naamlik die liefde van God vir God se skepsels. 
Maar andersyds: juis omdat dit om die liefde gaan, is hierdie uiteindelike of "finale" betekenis nooit heeltemal die laaste nie. Dit is nooit so definitief as 'n metafisiese prinsipe wat absoluut geld en waarteenoor iedere vraag verstom nie. Die nimmereindigende oneindig-heid van die nihilisme hang miskien saam met die feit dat die liefde as die "finale" betekenis van die openbaring geen egte einde ken nie. Ook hier is daar dus sprake van 'n duidelike raakpunt (of 'n wederkerigheid?) tussen die hedendaagse filosofie en 'n teologie wat sentreer rondom die idee van die oneindige liefde. Beide het aan die einde van die tydperk van die metafisika ontdek dat die geloof in 'n vaste grond, 'n causa prima as 'n voorstelbare objektiewe gegewe, nie meer haalbaar of selfs wenslik is nie, en dit omdat hulle albei bewus geword het van die geweld wat inherent is aan elke laaste woord, aan elke hoofbeginsel wat iedere verder-vra tot stilswye wil bring.

Die verkondiging wat in lyn is met die uitkomste van die eietydse filosofiese kritiek op die metafisiese geesteshouding is ' $n$ verkondiging wat Christus bo alles voorhou as ontmaskeraar. Trouens, die sin van die heilsgeskiedenis is presies geleë in die ontmaskering waarmee Christus 'n begin maak of, beter gestel: waarvan Hy uiteindelik die betekenis aantoon, aangesien die kenosis reeds met die skepping self en die Ou Testament begin. Die geloof hierin beteken dan nie dat ek alles wat in die evangelie en die dogmatiese leer van die kerk geskryf staan letterlik moet aanvaar nie, maar dat ek veral moet probeer om te begyp wat vir 'n betekenis die tekste van die evangelie vir my hier en nou het; met ander woorde om die "tekens van die tyd" te lees met geen ander voorbehoud as die liefde nie. Hierdie gebod kan nie gesekulariseer word nie, juis omdat dit gesien moet word as 'n "formele" kriterium, as 'n kritiese begrensing van die sekularisasie self, byna soos die Kantiaanse kategoriese imperatief.

Dat dit in die verkondiging primêr oor God se liefde gaan, en nie oor God se majesteit en almag nie, herinner sterk aan Dietrich Bonhoeffer se idee van 'n volwasse Christendom wat sigself nie rig op God as 'n soort deus ex machina, as die oplosser van alle probleme en konflikte nie, maar op 'n nie-almagtige God wat saam met nietige mense stry vir die verwerkliking van die goeie. Dit is 'n Christendom wat solidêr is met 'n groot deel van die verworwenhede van die moderne rede - sowel die teoretiese as die praktiese, tot by die rasionele organisasie van die samelewing, die liberale demokrasie, die kultuur van 
menseregte, en die volgehoue pogings om die lot van die gemarginaliseerdes en verdruktes te verbeter.

Om jou te vereenselwig met die stryd teen marginalisering en uitsluiting beteken egter nie om 'n nuwe rewolusionêre program op te stel nie. Kenmerkend van ons postmetafisiese tyd is juis 'n gesonde dosis skeptisisme jeens enige vorm van rewolusionêre utopisme, en hierdie skeptisisme is myns insiens die natuurlike gevolg van die sekularisasie. Ons kan nie meer glo dat die waarheid iewers in die marge sit, en dat daar dus - soos die Marxiste nog beweer het - 'n ideale "proletariaat" of 'n universele voertuig van bevryding sou bestaan wat bestem is om die ware betekenis van die geskiedenis aan die lig te laat tree nie. Hierdie skeptisisme weerhou die Christen egter nie van stryd teen enige vorm van geweld nie. Stryd teen die geweld wat verbonde is met die natuurlik-heilige is juis dit wat die menswording van Christus aan ons opdra. Hierdie stryd kan uiteraard nooit triomfantelik en hovaardig wees nie. As dit vanuit 'n houding van morele meerderwaardigheid gevoer word, sal dit onvermydelik self omslaan in liefdeloosheid en geweld. Kortom: Dit gaan hier om 'n etiek van die geweldloosheid, en prakties beteken dit om jou voortdurend te beywer vir die afname van geweld, in watter vorm ook al. Daarby moet die afname van die geweld gesien word as 'n steeds voortgaande proses, en nie as 'n ideale, suiwer toestand wat eens en vir altyd bewerkstellig sou word deur alle mense te laat konformeer aan die een of ander ewige essensie van die mens, die moraal, of die maatskappy nie.

\section{DIE KWESSIE VAN "SONDE" EN DIE NOODSAAK VAN VERLOSSING}

Die beswaar kan geopper word dat my gesekulariseerde en verswakte opvatting van die Christelike geloof die hardheid en gestrengheid wat die Goddelike geregtigheid kenmerk, verlore laat gaan en daarmee saam ook die eintlike sin van die sonde, die bestaan van die kwaad, en derhalwe ook die noodsaak van verlossing.

Hierop wil ek - miskien ietwat oordrewe - soos volg reageer: Vir my is die enigste betekenis van die woord sonde min of meer soos dié wat ons aantref in die uitroep "wat 'n sonde!"; dus om 'n verlore kans te betreur, of die beëindiging van 'n vriendskap, en in die algemeen die eindigheid van alles wat van waarde is en waaraan ons geheg is. Is dit nie so 
dat Jesus ons van ons sonde verlos ook en veral omdat Hy die nietigheid daarvan onthul nie? Sal met wat ons sonde noem, nie dieselfde gebeur as met die talle rituele voorskrifte van die Ou Testament, wat Jesus as voorlopig en nie meer noodsaaklik nie buite spel geplaas het? Nie slegs die sabbat nie ("Die sabbat is vir die mens en nie die mens vir die sabbat nie"), maar ook die besnydenis, wat geen onmisbare voorwaarde meer is om tot die volk van God te behoort nie. Wat verhinder ons om te dink dat ook die ander sondes, wat ons nog as sodanig beskou, nie bestem is om eenmaal in dieselfde lig onthul te word nie?

Weerstand teen hierdie gedagte hang saam met die idee dat daar sondes is wat juis as sodanig te definieer is op basis van ' $n$ natuurwet, dus op basis van 'n metafisiese opvatting van essensies. Maar hierdie metafisiese opvatting is niks anders nie as die verabsolutering van een of ander histories bepaalde wêreldbeskouing wat, soos elke kulturele voortbrengsel van die mens, miskien respek verdien (uit liefde vir die naaste), maar niks meer as dit nie. Ja, kan mense sê, maar sal daar nie ook 'n dag aanbreek waarop die gebod "Jy mag nie doodslaan nie" gesekulariseer word nie? Hier wil ek herinner aan my vroeëre opmerking dat die norm (die grens) van die sekularisasie die liefde is, en in meer spesifieke, etiese terme, die vermindering van geweld in alle vorme: dus geen sekularisasie van die sonde van doodslag nie. Die norm van die liefde geld behalwe vir moord ook vir die skandaal, dit wil sê dit dwing 'n sekere respek af vir die morele verwagtinge van andere en van die gemeenskap waarin ek leef, wat nie sommer verkleineer kan word alleen maar uit naam van die "waarheid" wat ek na bewering in pag sou hê nie.

Met hierdie grens voor oë is dit inderdaad moontlik om die optrede van Jesus teen die kwaad as ' $n$ ironiese ontbinding daarvan te bedink. Dit sou totaal die teenoorgestelde wees van die gedrag van sovele Christene wat hulle verplig voel om die ontsaglike mag van die kwaad in die wêreld aan te dik, so asof dit 'n manier sou wees om die reddende vermoë van Hom wat ons daarvan verlos, te benadruk. Die Ou Testament, en ook enkele bladsye uit die Nuwe Testament, wemel van situasies waarin die Goddelike geregtigheid skynbaar op skrikwekkende wyse tot uitvoering kom, dikwels net so wreed soos die gebruike van die toenmalige samelewings (vgl bv die ysingwekkende slot van Ps 137). Ek kry egter die indruk dat daar in die Nuwe Testament minder bladsye oor "geregtigheid" as oor "barmhartigheid" te vinde is. Dit versterk my in die oortuiging dat die verhouding tussen die twee gesigte van God in werklikheid twee verskillende momente in die heilsge- 
skiedenis verteenwoordig, en dat die Goddelike geregtigheid 'n attribuut is wat nog heel digby die natuurlike idee van die heilige staan, wat juis uit naam van die grootste gebod van die liefde "gesekulariseer" moet word.

Maar sal God volledig kan afsien van die funksie van regter en nooit meer die onregverdighede by die naam noem nie? Sal die godsdiens nie ook en veral honger en dors na geregtigheid nie - 'n geregtigheid wat selde op hierdie aarde verwesenlik word en dus in die ewigheid herstel moet word, met die persoonlike oordeel (waaraan elkeen by sy of haar dood onderwerp word) en met die universele laaste oordeel? Maar as ons verwag dat God alleen maar moet regspreek, soortgelyk aan 'n menslike tribunaal behalwe dat God met volmaakte ewewigtigheid en onfeilbaarheid begaafd is, wat doen ons dan met God se belofte om die sonde te vergewe? Ook die uitvlug om te sê dat God alleen diegene vergewe wat dit verdien, veral deur berou te toon vir wat hulle gedoen het, sou nogal 'n powere oplossing wees vir die behoefte om 'n versteurde ewewig te herstel. Dit sal nie genoeg wees om aan diegene wie se gesin deur ' $n$ moord verwoes is, of aan die oorlewendes van die holocaust genoegdoening te gee nie.

God kan heel goed regter wees en tog ook vergewe; dit is juis die misterie waarmee ons rekening moet hou. Maar hierdie misterie sou miskien minder ondeurgrondelik word as ons erken dat ons almal behoefte aan vergewing het. Nie soseer omdat ons heilige beginsels geskend het nie, maar omdat ons "gefaal" het teenoor hulle wat ons moes liefhê God self miskien, en ons naaste in wie se gedaante God aan ons verskyn.

\section{SLOT: 'N "VRIENDELIKER" CHRISTENDOM}

My hele betoog tot dusver kan miskien saamgevat word as 'n pleidooi, nie soseer vir 'n "gemakliker" Christendom nie, as vir 'n "vriendeliker" een. My "positiewe" opvatting van die sekularisasie, en my ietwat ongebruiklike siening van die sonde en die kwaad van hierdie wêreld, kan my moontlik die verwyt van lighartigheid en onverskilligheid op die hals haal. Daar sal ongetwyfeld dié wees wat verkies om die nadruk eerder te lê op die werklikheid van die kwaad, op die onoorkombaarheid van die menslike tekortkomings, op die idee van die geskiedenis as oord van lyding en beproewing pleks van heilsgeskiedenis. Dit sou die tipiese voorstanders wees van wat ek die tragiese Christendom genoem het. Maar ek meen dat die verwyt van ongevoeligheid vir die kwaad in die wêreld maklik op hulle om- 
gekeer kan word. Immers, veel te dikwels het die nadruk op die realiteit van die kwaad wat dan met menslike middele onoorkombaar sou wees tot gevolg gehad, ook in die geskiedenis van die kerk, dat die wêreldlike nood en behoeftes maar met gelatenheid aanvaar en in die hande van die goddelike genade oorgelaat is. Deur God se menswording, in alle betekenisse van die kenosis, maak God daarenteen 'n historiese betrokkenheid moontlik, opgevat as die effektiewe verwesenliking van die verlossing en nie alleen maar as aanaarding van ' $n$ beproewing of ' $n$ soeke na verdienstes met die oog op die hiemamaals nie.

Ek glo dus nie dat die optimisme wat verbonde is met die lesing van die Christelike openbaring in terme van "verswakking," noodsaaklikerwys tot 'n onderwaardering van die node en behoeftes van die wêreld lei nie. Wat ek wel glo, is dat Christene, in plaas daarvan om hulle op te stel as verdedigers van sogenaamde onaantasbare en sakrale "waardes," juis moet optree as geweldlose anargiste, as ironiserende dekonstrueerders van die aansprake van die historiese ordeningsisteme, en dit terwyl hulle gelei word deur die gebod van die liefde teenoor die ander, en nie die soeke na groter gemak vir hulleself nie. Die keuse tussen 'n tragiese visie en sekularisasie kan ten slotte slegs geskied met 'n verwysing na 'n eskatologiese "norm." So 'n norm is die liefde, wat bestem is om voort te leef ook wanneer geloof en hoop nie meer nodig sal wees sodra God se ryk heeltemal verwesenlik is nie. 'n Derglike norm regverdig volgens my volledig die voorkeur vir 'n "vriendelike" opvatting van God en van die godsdiens. As dit van 'n oormaat aan vriendelikheid getuig, dan het God self die voorbeeld daarvan vir ons gegee.

\section{Literatuurverwysings}

Barth, K 1926. Der Römerbrief. München: Kaiser.

- 1961. Church Dogmatics. A selection (ed G W Bromiley). Edinburgh: Clark.

Bonhoeffer, D 1981. Letters and papers from the prison. London: SCM.

Dilthey, W 1988. Introduction to the human sciences. Detroit: Wayne State University Press.

Elias, N 1982. The civilizing process. Oxford: Blackwell.

Feuerbach, L 1966. The essence of Christianity. New York: Harper \& Row.

Freud, S 1969. Moses and monotheism. New York: Vintage. 
Freud, S 1985. Civilization, society and religion: Group psychology, civilization and its discontents and other works. Harmondsworth: Penguin.

Gehlen, A 1978. Die Sekularisierung des Fortschritts, in Einblicke (Werke, Band 7). Frankfurt a M: Klostermann.

Girard, R 1972. Violence and the sacred. Baltimore: Johns Hopkins University Press.

Gogarten, F 1953. Verhängnis und Hoffnung der Neuzeit: Die Sekularisierung als theologisches Problem. Stuttgart: Kohlhammer.

- 1970. Christ the crisis. London: SCM.

Heidegger, M 1957. Identität und Differenz. Pfullingen: G Neske.

- 1961. Nietzsche (Zweiter Band). Pfullingen: G Neske

- 1986. Der Satz vom Grund. Pfullingen: G Neske.

- 1978. Vorträge und Aufsätze. Pfullingen: G Neske.

- 1967. Wegmarken. Frankfurt a M: Klostermann.

Lübbe, H 1975. Sekularisierung: Geschichte eines ideenpolitischen Begriffs. Freiburg: Alber.

Lyotard, J-F 1984. The postmodern condition. Manchester: Manchester University Press.

Marx, K 1976. Early writings. Harmondsworth: Penguin.

Nietzsche, F 1968. Twilight of the idols and the anti-Christ. Harmondsworth: Penguin.

Troeltsch, E 1906. Die Bedeutung des Protestantismus für die Entstehung der modernen Welt. München: Oldenbourg.

Schürmann, R 1987. Heidegger on being and acting: From principles to anarchy. Bloomington: Indiana University Press.

Vattimo, G 1988. The end of modernity: Nihilism and hermeneutics in post-modern culture. Cambridge: Polity Press.

Weber, M 1978. The protestant ethic and the spirit of capitalism. London: Unwin. 